\title{
Assessment of safety culture in a public hospital in the Federal District, Brazil
}

\author{
Avaliação da cultura de segurança em um hospital público no Distrito Federal, Brasil \\ Evaluación de la cultura de seguridad en un hospital público en el Distrito Federal, Brasil
}

Paloma Aparecida Carvalho'

ORCID: 0000-0002-5795-6631

Carla Albina Soares Laundos' ORCID: 0000-0001-7399-3574

Juliana Ventura Souza Juliano' ORCID: 0000-0002-6299-7745

Luiz Augusto Casulari" ORCID: 0000-0002-1315-4127

Leila Bernarda Donato Gottems ${ }^{11,1 \mathrm{IV}}$ ORCID: 0000-0002-2675-8085

'Centro Universitário do Distrito Federal. Brasília, Distrito Federal, Brazil. "Universidade de Brasília. Brasília, Distrito Federal, Brazil.

"'Universidade Católica de Brasília. Brasília, Distrito Federal, Brazil.

"Escola Superior de Ciências da Saúde. Brasília, Distrito Federal, Brazil.

How to cite this article: Carvalho PA, Gottems LBD, Motta LACR, Laundos CAS, Juliano JVS. Assessment of safety culture in a public hospital in the Federal District, Brazil. Rev Bras Enferm [Internet]. 2019;72(Suppl 1):252-8. [Thematic Issue: Work and Management in Nursing]. DOI: http://dx.doi.org/10.1590/0034-7167-2017-0716

Corresponding Author:

Paloma Aparecida Carvalho

E-mail: paloma_carvalho@yahoo.com.br

Submission: 11-13-2017

Approval: 06-06-2018

\section{ABSTRACT}

Objective: to assess the perception of health professionals regarding safety culture of a high complexity public hospital of the Federal District, Brazil. Method: crosssectional and descriptive study. The Safety Attitudes Questionnaire was used in electronic format. Descriptive and inferential analyses were carried out. Results: 358 professionals participated, with $242(67.6 \%)$ being female. Of these, 224 (62.6\%) worked directly or indirectly with patients in assistance activities; 79 (22.1\%) in administrative activities; $14(3.9 \%)$ in management; and $41(11.5 \%)$ in others. The total score was 57.1. Job satisfaction factors and stress perception had the most expressive results, 76.2 and 68.8, respectively. The category "working conditions" presented the lowest result, 40.7. Conclusion: the results are below the score of 75 , value recommended as indicative of a positive safety atmosphere. We suggest the implementation of actions for the promotion of safety culture and new studies with representative samples of all segments of workers.

Descriptors: Quality of Health Care; Patient Safety; Organizational Culture; Health Services Assessment; Health Services Research.

\section{RESUMO}

Objetivo: avaliar a percepção dos profissionais de saúde sobre a cultura de segurança de um hospital público de alta complexidade do Distrito Federal, Brasil. Método: estudo transversal e descritivo. Utilizou-se o Questionário Atitudes de Segurança no formato eletrônico. Foram realizadas análises descritivas e inferenciais. Resultados: participaram 358 profissionais, sendo 242 (67,6\%) do sexo feminino. Destes, 224 (62,6\%) trabalhavam direta ou indiretamente com o paciente em atividades assistenciais; 79 $(22,1 \%)$ em administrativas; 14 (3,9\%) em gerenciais; e $41(11,5 \%)$ em outras. $O$ escore total foi de 57,1 ; os fatores satisfação no trabalho e percepção do estresse tiveram os resultados mais expressivos, 76,2 e 68,8 , respectivamente. $O$ quesito condições de trabalho teve o resultado mais baixo, 40,7 . Conclusão: os resultados estão abaixo do escore 75, valor recomendado como indicativo de um clima de segurança positivo. Sugere-se a implementação de ações para a promoção da cultura de segurança e novos estudos com amostra representativa de todos os segmentos de trabalhadores.

Descritores: Qualidade da Assistência à Saúde; Segurança do Paciente; Cultura Organizacional; Avaliação de Serviços de Saúde; Pesquisa sobre Serviços de Saúde.

\section{RESUMEN}

Objetivo: evaluar la percepción de los profesionales de salud sobre la cultura de seguridad de un hospital público de alta complejidad del Distrito Federal, Brasil. Método: estudio transversal y descriptivo. Se utilizó el Cuestionario Actitudes de Seguridad en el formato electrónico. Se realizaron análisis descriptivos e inferenciales. Resultados: participaron 358 profesionales, siendo 242 (67,6\%) mujeres. De estos, 224 $(62,6 \%)$ trabajaban directa o indirectamente con el paciente en actividades asistenciales; $79(22,1 \%)$ en administrativas; $14(3,9 \%)$ en gerenciales; y $41(11,5 \%)$ en otras. La puntuación total fue de 57,1 ; los factores de satisfacción en el trabajo y percepción del estrés tuvieron los resultados más expresivos, 76,2 y 68,8 , respectivamente. La categoría de las condiciones de trabajo tuvo el resultado más bajo, 40,7. Conclusión: los resultados están por debajo de la puntuación 75 , valor recomendado como indicativo de un clima de seguridad positivo. Se sugiere la implementación de acciones para la promoción de la cultura de seguridad y nuevos estudios con muestra representativa de todos los segmentos de trabajadores.

Descriptores: Calidad de la atención de Salud; Seguridad del Paciente; Cultura Organizacional; Investigación en Servicios de Salud. 


\section{INTRODUCTION}

The term safety culture was first used by the International Nuclear Safety Group (INSAG), after the nuclear accident at Chernobyl and, since then, has been used by organizations considered of high risk ${ }^{(1)}$. In health, safety culture is described as the product of values, attitudes, perceptions, competencies, and patterns of individual and group behavior that determine the commitment of a healthcare organization management with the patient's safety ${ }^{(2)}$.

Organizations with positive safety culture are characterized by good communication among professionals, mutual trust, and common perceptions about the importance of safety and the effectiveness of preventive actions $s^{(2)}$. The term safety climate is used with little or no differentiation from the term safety culture ${ }^{(1,3)}$, defined as the surface characteristics of safety culture from the perceptions and attitudes of individuals at a given point of time, or as the measurable components of safety culture ${ }^{(4)}$.

Users, administrators, and professionals are increasingly concerned with the quality of health services. Users are more informed and participate more, while administrators are concerned with an optimal utilization of resources and know that efficiency, among other benefits, lowers costs. Health professionals, in addition to seek survival in the market, are concerned with quality due to the area's intrinsic ethical commitment, which involves taking care of the most valuable asset of a person, his/her health ${ }^{(5)}$.

Quality in health depends on a number of dimensions, including safety ${ }^{(6)}$. In Brazil, the National Program of Patient Safety (PNSP) was established in 2013, with the goal of qualifying health care. In this program, safety culture is developed from five characteristics: all workers are encouraged to take responsibility for their own safety, as well as their colleagues', patients' and family members'; safety is prioritized over financial and operational goals; identification, notification, and resolution of safety-related issues are encouraged and rewarded; organizational learning from incidents is promoted; resources, structure, and accountability for the effective maintenance of safety are provided ${ }^{(7)}$.

The implementation of the program provides for the promotion of safety culture with emphasis on learning and organizational improvement regarding the involvement of professionals and patients in preventing incidents, especially insurance systems, avoiding individual accountability processes ${ }^{(7)}$. Also in 2013, health organizations started to form the Patient Safety Centers, which must adopt the systematic dissemination of safety culture ${ }^{(8)}$. In this perspective, to measure the safety climate is an important strategy for monitoring the improvement of health care quality, as it enables the balancing of actions between the dimensions that present major weaknesses and those with better performances.

\section{OBJECTIVE}

To assess the perception of health professionals who work at a high complexity public hospital, part of the Brazilian Unified Health System (SUS), of the Federal District, Brazil, regarding safety culture.

\section{METHOD}

\section{Ethical aspects}

This research followed all the ethical precepts of Resolution No. 466, December 12, 2012(9), of the National Health Council. The project was approved by the Research Ethics Committee of the Foundation for Education and Research in Health Sciences, of the Federal District Health Department, on October 6, 2014.

\section{Study design, location, and period}

A cross-sectional and descriptive study was carried out between July and September 2015 in a general hospital of special size in the Federal District. It is a high complexity public institution, with 650 beds, according to data from the National Register of Health Establishments (CNES), having as reference June 2015.

\section{Population and sample: inclusion and exclusion criteria}

The study population was composed of all the professionals working in the institution at the time of collection, including 3,757 professionals of varied training levels and areas of expertise, according to the CNES. The sample consisted of all the professionals who were in office during the period of data collection. Due to restrictions on access to human resources information, we were unable to estimate the number of professionals who were not working due to provided for reasons, such as vacation and scheduled licenses, and for unforeseen reasons, as medical licenses and others. In this study, we did not calculate the sample. Instead, we chose to work with the general response rate, calculated by dividing the number of professionals who responded by the total number of professionals in the institution and multiplying the result by 100 .

\section{Study protocol}

The Safety Attitudes Questionnaire (SAQ) was used, translated and culturally adapted to Brazil. It is a self-applied instrument (the participants read, interpret, and respond), divided into two parts. The first is composed by 41 statements that compose 6 aspects: teamwork climate (1 to 6$)$, safety climate (7 to 13$)$, job satisfaction (15 to 19), stress perception (20 to 23), management perception (24 to 28), and working conditions (29 to 32). Statements 14 and 33 to 36 do not belong to any of the aspects, but are added to the total score. The second part collects data that characterize the professionals regarding sex, occupation and years of experience in the area ${ }^{(10)}$.

The answers follow a five-point Likert scale, coded as follows: strongly disagree (1) equals 0 points; partially disagree (2) equals 25 points; neutral (3) equals 50 points; partially agree (4) is equal to 75 points; and totally agree (5) is equivalent to 100 points. The instrument result varies from 0 to 100 , with 0 representing the worst and 100 the best perception of the safety climate. The values are considered positive when the total score is greater than or equal to $75^{(10)}$. 
Assessment of safety culture in a public hospital in the Federal District, Brazil Carvalho PA, Gottems LBD, Motta LACR, Laundos CAS, Juliano JVS.

The score is calculated as follows: (1) the reverse items are reversed and re-encoded (questions 2, 11, and 36), i.e., the answer "strongly disagree" becomes "totally agree", and so on; (2) the statements are grouped by aspects; (3) the answers to the statements in each aspect are summed and divided by the number of statements in each aspect ${ }^{(10)}$.

For this research, we opted for electronic collection. The questionnaire was made available to the professionals' electronic mail (e-mail), provided by the hospital, and on the website of the research, so that respondents could answer when was more convenient. Mechanisms of e-mail receiving confirmation were not used. For dissemination and sensitization, we used posters and folders containing explanatory information about the research and the invitation to the professional to participate.

Initially, the research was disseminated and we waited for the professionals' adherence. However, after the first month of collection, noting the low rate of response, we opted for in locus collection. In this step, a team was trained to collect the answers through mobile devices so that the professionals had access to the questionnaire. The collection team invited the professionals to participate of the research at their work places, during their working hours. Those who accepted received the mobile device to read the informed consent form and, after consenting, progressed to the reading and answering of the questionnaire. The collecting team did not intervene, since it is a self-filled questionnaire. However, they remained close to receive the mobile device back at the end. The collection was carried out during the three working shifts (morning, afternoon, and evening), in the seven days of the week, between August and September 2015.

\section{Analysis of the results and statistics}

Descriptive and inferential analyses were carried out using the Statistical Package for the Social Sciences 20.0. For the internal consistency analysis of the items, also called the reliability of the instrument, the Cronbach's a coefficient was applied. The a varies from 0 to 1 , however, to prove internal consistency, it must present a value between 0.7 and 1.0. Results below 0.7 indicate that the instrument cannot measure the proposed factors ${ }^{(11)}$. An analysis of variance (Anova) was carried out using Turkey test to compare the dimensions' averages.

\section{RESULTS}

358 professionals participated on the study, which corresponds a $9.5 \%$ response rate. In Table 1, it is possible to observe that the participants were predominantly female $(242,68 \%)$, and that the most frequent age group was from 30 to 59 years, with 262 professionals (73\%). Nursing technicians and assistants were the ones who participated most in this study $(n=113 ; 31.6 \%)$, followed by nurses ( $n=53 ; 15 \%)$, administrative technicians $(n=36 ; 10 \%)$, operational assistant of various services $(n=28 ; 8 \%)$, physicians $(\mathrm{n}=21 ; 6 \%)$, and residents of medicine, nursing, and nutrition $(n=14 ; 4 \%)$. The most frequent area was assistance $(n=224 ; 63 \%)$, followed by administration ( $n=79 ; 22 \%)$, management $(n=14$; $4 \%)$ and others $(n=41 ; 12 \%)$. As for the time of professional performance, most participants had between 11 and 20 years on the job $(n=95 ; 27 \%)$.
Table 1 - Participants' profile, Brasília, Federal District, Brazil, 2016

\begin{tabular}{|c|c|c|}
\hline Variable & $\mathbf{n}$ & (\%) \\
\hline \multicolumn{3}{|l|}{ Sex } \\
\hline Female & 242 & 68 \\
\hline Male & 116 & 32 \\
\hline \multicolumn{3}{|l|}{ Age group (years) } \\
\hline 17 to 29 & 79 & 22 \\
\hline 30 to 59 & 262 & 73 \\
\hline Over 60 & 6 & 2 \\
\hline Missing data & 11 & 3 \\
\hline \multicolumn{3}{|l|}{ Position } \\
\hline Nursing technician & 83 & 23 \\
\hline Nurse & 53 & 15 \\
\hline Administrative technician & 36 & 10 \\
\hline Nursing assistant & 30 & 8 \\
\hline Operational assistant of various services & 28 & 8 \\
\hline Health technician & 26 & 7 \\
\hline Physician & 21 & 6 \\
\hline Resident & 16 & 4 \\
\hline Student or intern & 12 & 3 \\
\hline Physical therapist & 12 & 3 \\
\hline Pharmacist & 6 & 2 \\
\hline Nutritionist & 6 & 2 \\
\hline Other & 29 & 8 \\
\hline \multicolumn{3}{|l|}{ Area of practice } \\
\hline Assistance & 224 & 63 \\
\hline Administration & 79 & 22 \\
\hline Management & 14 & 4 \\
\hline Other & 41 & 12 \\
\hline \multicolumn{3}{|l|}{ Time of professional performance (years) } \\
\hline 11 to 20 & 95 & 27 \\
\hline 21 or more & 74 & 21 \\
\hline 5 to 10 & 61 & 17 \\
\hline 1 to 2 & 54 & 15 \\
\hline 3 to 4 & 48 & 13 \\
\hline Less than 6 months & 19 & 5 \\
\hline 6 to 11 months & 7 & 2 \\
\hline Total & 358 & 100 \\
\hline
\end{tabular}

The results of SAQ showed a total score of 57.1. In the dimensions analysis, job satisfaction factors and stress perception had the most expressive results, 76.2 and 68.8 , respectively.

The teamwork climate and safety climate had the same score (58.2), followed by unit management perception, with 55.2. Hospital management perception and working conditions had the lowest results, with 42.2 and 40.7 , respectively.

The Cronbach's a in this study was 0.86 , which demonstrates good reliability for being between 0.7 and $1.0^{(11)}$. In the analysis of variance (Anova) carried out by Turkey test for comparison between the aspects' averages, we observed significant differences ( $p<0.05)$ when comparing: job satisfaction with management perception $(p<0.001)$ and working condition $(p<0.001)$; management perception with job satisfaction $(p<0.001)$ and stress perception $(p<0.002)$; stress perception with management perception $(p<0.002)$ and working conditions $(p<0.001)$; and working conditions with job satisfaction $(p<0.001)$ and stress perception $(p<0.001)$. 
Table 2 - Average score and standard deviation of dimensions and of the total of the Safety Attitudes Questionnaire, Brasília, Brazil, 2016

\begin{tabular}{lcc}
\hline Dimension & Average & $\begin{array}{c}\text { Standard } \\
\text { deviation }\end{array}$ \\
\hline Teamwork climate & 58.2 & 23.1 \\
Safety climate & 58.2 & 21.0 \\
Job satisfaction & 76.2 & 20.7 \\
Stress perception & 68.8 & 23.5 \\
Unit management perception & 55.2 & 20.7 \\
Hospital management perception & 42.2 & 19.9 \\
Working conditions & 40.7 & 25.6 \\
Total & 57.1 & 12.9 \\
\hline
\end{tabular}

\section{DISCUSSION}

The number of participants was low, although the strategy used in this study followed the methodology proposed by national and international studies carried out with the same instrument, in which the questionnaire is made available to the largest possible number of professionals and voluntary return is expected. The use of the form in electronic format may have contributed to the low adherence, however, considering that the collection period was extensive (two entire months) and that disclosure of the research was intensive, we believe that the results were influenced by other factors, such as organizational culture itself.

The institution does not have a history of carrying out assessments of this type. Prior to this study, the Surgical Center of the institution was subject to the instrument's validation ${ }^{(12)}$, but no other assessments were carried out. Despite the low number of participants, we believe that the results can be used as a baseline for future evaluations. However, we stress the importance of ensuring the participation of all categories of professionals through stratified sampling.

The participants' profile showed predominance of the female sex. In studies conducted in Brazil, the predominance of the female sex and of professionals belonging mostly to the nursing staff were also observed $^{(10,12-13)}$. The predominance of women among the nursing workers is a historical feature that has been reduced, in line with the social and cultural changes, but is still perceived in the society and health services in Brazil, according to a research conducted in 2013, which showed female predominance (85\%) in this profession ${ }^{(14)}$.

Regarding age and time of professional performance, the highest frequency was of the age group from 30 to 59 years and of professionals who have been working from 11 to 20 years in the same area. We observed that professionals with 11 years or more of professional performance represent $47.2 \%$ of the total of participants. It is believed that this trait can be explained by the fact that the professionals are public servants, who have stability, which can influence the entry and stay of professionals at the institution ${ }^{(15)}$. A study that investigated the factors involved in patient safety with focus on the hospital nursing staff showed that turnover and lack of stability are factors that interfere with patient safety ${ }^{(16)}$. Thus, it is assumed that this trait can contribute to the strengthening of safety culture.

As for the type of work, assistants were the most frequent, followed by the administrative area, management, and others.
This distribution is compatible with the number of professionals by practice area, as the number of employees working in the administrative and management areas is substantially less than the number of those working in assistance. It is important to stress that the participation of the three performance areas is essential for the assessment of safety culture, which is built and sustained by the values of all professionals, including from the leadership to the areas that are not directly linked to assistance, as described in PNSP(7).

SAQ results show a total score of 57.1, below the recommend value (75). Scores below 60 demonstrate the need to implement actions directed to the development of a positive safety culture ${ }^{(17)}$. Despite the low response rate, since in similar studies it fluctuated between 40 and $94 \%{ }^{(10,13)}$, this result is close to that obtained in the assessment made in the surgical center of the same institution, which was of $53.5^{(12)}$, suggesting a coherent result. However, to ensure reliability, we suggest that new assessments are carried out with a stratified sample.

The analysis of the dimensions showed that job satisfaction presented the best average. This same dimension presented smaller averages in Ireland (67.9) and Taiwan (42.1)(18-19). In other Brazilian studies, the averages ranged from 77 to $83^{(10,12-13,20)}$. It is possible to observe in the Brazilian studies this is the dimension that presents the best performance. In this study, we believe that the fact that the professionals are public servants, who have work stability ${ }^{(16)}$, may have influenced such aspect. Therefore, we suggest further studies should be carried out, correlating these variables.

Stress perception presented an average considered positive. This aspect has shown favorable results both in Brazilian studies, with averages oscillating between 69 and $81^{(10,12-13,20)}$, and studies conducted in other countries, with averages between 68 and $80^{(21-23)}$. Recognizing that stress can affect the results in health care is an essential stance to reduce unsafe occasions.

The teamwork climate presented a value below the indicated for a positive safety climate, consistent with results identified in China (48.9) $)^{(19)}$ and other Brazilian studies (59.1 $1^{(12)}$ and 69.5 $\left.5^{(10)}\right)$. A recent study conducted in three Brazilian hospitals found more favorable results, with averages between 73 and $75^{(13)}$, which may be a reflection of the patient safety policies imposed in $2013^{(7-8)}$.

Regarding the safety climate, we observed a higher average (58.2) than the result found in a research conducted in the surgical center of the same institution in 2013, whose average was $48.9^{(12)}$. The most positive result shows that the aspects may fluctuate substantially within the same institution, depending on who participated in the study and when it is performed, which suggests the need for methodological rigor to ensure trustworthy and reliable results. However, it is also possible to attribute the more favorable result to the effect of patient safety policies adopted by the institution ${ }^{(7-8)}$. Safety climate has shown positive results in developed countries, such as Ireland (65.9) ${ }^{(18)}$, Sweden $(78)^{(22)}$, and the United States of America (72) ${ }^{(24)}$, where policies and investments in quality and patient safety began earlier than in Brazil.

Unit management perception and hospital management perception presented low averages. Brazilian studies also have found negative results for these aspects in both selections, unit and hospital, with averages fluctuating from 44.5 to 60 and 34.5 to 64 , respectively ${ }^{(10,13)}$. It is important to note that even in countries that have more experience with policies of quality and 
patient safety, such as Ireland and the United States of America, this aspect has presented the most negative results among the six aspects of SAQ ${ }^{(18,24)}$.

The working conditions aspect presented the lowest average. This aspect has shown weakness in studies carried out in Brazil $^{(10,12-13)}$. In studies conducted in other countries, this aspect showed more favorable results, oscillating between 61 and $84^{(21-23)}$. Investments in infrastructure, basis for working conditions, are indispensable for achieving and maintaining minimum safety conditions in high-risk organizations, such as health institutions.

The analysis of variance between the aspects showed correlation between job satisfaction and management perception and working conditions. There is also correlation between management perception and stress perception. It is important to recognize that, in Brazil, work in the health sector, especially the one developed by the nursing staff, has been hindered by problems related to a shortage of human resources and materials, lack of qualification, excessive workload, absenteeism, and evasion from the profession, due to structural, political, economic, and cultural issues which have been blamed, by the media, for the recurrent errors and failures in patient care ${ }^{(25)}$.

Measuring safety climate is one of the strategies to improve the quality of health services, as it makes it enables the identification of the aspects that require greater attention and efforts to develop a positive safety culture, aligned to continuous improvement. It is believed that a negative safety culture, in which the punitive culture, focused on finding someone to blame for the incidents, prevail, can contribute to the support of an insecure organizational climate, more prone to the occurrence of adverse events.

The literature has pointed out that the overall median incidence of adverse events in hospitalized patients is around $9.2 \%$ and that the proportion of preventable adverse events is around $43.5 \%{ }^{(26)}$. In Brazil, a recent study that evaluated the occurrence of adverse events in hospitalized patients pointed out a prevalence of $12.8 \%$ of these events, with $42.7 \%$ of them being preventable ${ }^{(27)}$. Recognizing that incidents occur is an important step to walk the path of improving safety in health care. A positive culture strongly contributes in this direction, as it provides for a welcoming organizational climate in which events are recognized and treated technically, free of culpability, with proper tools and scientific knowledge to minimize recurrence and harmful consequences.

It should be noted that incidents that happen cannot be confused with trivialization and acceptance of inconsequential errors as "inevitable". On the contrary, this attitude of recognition is enhanced by the maturity of understanding that complex systems, such as health care, are subjected to errors, but they can be minimized and even avoided when treated properly ${ }^{(28)}$. A positive culture contributes for a resilient system that gives sustainability to established relations within the health system, among professionals, users, and administrators, who seek the same goal: health, in its most complete definition.

\section{Study limitations}

The study has as limitation the low response rate (9.5\%). It should be noted that this was the first study of this theme carried out at the analyzed hospital, which may have contributed to the low adherence of professionals to answer the questionnaire. We believe that the promotion of a fair, and not punitive, culture, allied to new assessments shall allow professionals to feel more comfortable and safe to participate. Therefore, further studies are necessary to continue this assessment and complement the results found.

\section{Contributions to the field of nursing, health, or public policy}

The study forms a baseline for monitoring safety culture in the analyzed hospital. According to the public policies of patient safety in Brazil, assessment is essential for the promotion of safety culture in health establishments, as it allows the directing of actions according to the performance of the analyzed aspects, as well as evaluating specific actions, such as the implementation of protocols and programs of continued education, with the purpose of measuring their impact on safety culture. The assessment has also been used to evaluate the adherence of professionals to the notification systems of adverse events.

It is evident that the assessment of safety culture contributes to improve the quality of care in health services, as it allows the viewing of the culture's measurable portion (safety climate) and use it as an indicator to shows to which direction the health establishment is walking.

\section{CONCLUSION}

The result of the total score of the SAQ was below the recommended (75), which suggests that the institution must implement actions focused on the development of a positive safety culture. We suggest that the results found in this study are used by administrators to target investments in the implementation of actions that promote a positive and favorable safety climate to promote patient safety.

It is imperative that there is commitment regarding the political, strategic, and operational levels, in an integrated mobilization, involving all professionals - from hospital management, passing by rearguard professionals, who provide the subsidies and resources for assistance, to front-line professionals, who provide direct assistance to patients -, so that patient safety culture is implemented fully and perennially.

\section{FUNDING}

This study was funded by the Foundation for Education and Research in Health Sciences, of the Federal District Health Department.

\section{REFERENCES}

1. Flin R, Burns C, Mearns K, Yule S, Robertson EM. Measuring safety climate in health care. Qual Saf Health Care [Internet]. 2006 [cited 2016 Aug 4];15(2):109-15. Available from: https://www.ncbi.nlm.nih.gov/pmc/articles/PMC2464831/pdf/109.pdf 
2. Nieva V, Sorra J. Safety culture assessment: a tool for improving patient safety in healthcare organizations. Qual Saf Health Care [Internet]. 2003 [cited 2016 Aug 20];12(Suppl 2):ii17-ii23. Available from: https://www.ncbi.nlm.nih.gov/pmc/articles/PMC1765782/pdf/v012p0ii17.pdf

3. Halligan M, Zecevic A. Safety culture in healthcare: a review of concepts, dimensions, measures and progress. BMJ Qual Saf [Internet]. 2011 [cited 2016 Aug 17];20(4):338-43. Available from: http://qualitysafety.bmj.com/content/20/4/338

4. Colla J, Bracken A, Kinney L, Weeks W. Measuring patient safety climate: a review of surveys. Qual Saf Health Care [Internet]. 2005 [cited 2016 Aug 15];14(5):364-6. Available from: https://www.ncbi.nlm.nih.gov/pmc/articles/PMC1744072/pdf/v014p00364.pdf

5. Gama ZAS, Saturno PJ. A segurança do paciente inserida na gestão da qualidade dos serviços de saúde. In: Agência Nacional de Vigilância Sanitária (BR). Assistência segura: uma reflexão teórica aplicada à prática [Internet]. 1a ed. Brasília: Agência Nacional de Vigilância Sanitária; 2013 [cited 2016 Aug 28]. p. 29-40. (Série Segurança do paciente e qualidade em serviços de saúde). Available from: http://www20.anvisa. gov.br/segurancadopaciente/images/documentos/livros/Livro1-Assistencia_Segura.pdf

6. Institute of Medicine (US), Committee on Quality of Health Care in America. Crossing the quality chasm: a new health system for the 21 st century [Internet]. Washington (DC): National Academies Press (US); 2001 [cited 2016 Aug 20]. Available from: http://www. nationalacademies.org/hmd/ /media/Files/Report\%20Files/2001/Crossing-the-Quality-Chasm/Quality\%20Chasm\%202001\%20\%20 report\%20brief.pdf

7. Ministério da Saúde (BR), Fundação Oswaldo Cruz, Agência Nacional de Vigilância Sanitária. Documento de referência para o Programa Nacional de Segurança do Paciente [Internet]. Brasília: Ministério da Saúde; 2014 [cited 2016 Aug 20]. Available from: http://bvsms.saude. gov.br/bvs/publicacoes/documento_referencia_programa_nacional_seguranca.pdf

8. Ministério da Saúde (BR), Agência Nacional de Vigilância Sanitária. Resolução da Diretoria Colegiada n 36, de 25 de julho de 2013 [Internet] Diário Oficial da União: República Federativa do Brasil. 2013 Jul 26 [cited 2016 Aug 25];1:32. Available from: http://bvsms.saude.gov.br/bvs/ saudelegis/anvisa/2013/rdc0036_25_07_2013.html

9. Ministério da Saúde (BR), Conselho Nacional de Saúde. Resolução n 466, de 12 de dezembro de 2012. Aprova as diretrizes e normas regulamentadoras de pesquisas envolvendo seres humanos [Internet]. Diário Oficial da União: República Federativa do Brasil. 2013 Jun 13 [cited 2018 Aug 14];1:59. Available from: http://bvsms.saude.gov.br/bvs/saudelegis/cns/2013/res0466_12_12_2012.html

10. Carvalho REFL, Cassiani SHB. Questionário Atitudes de Segurança: adaptação transcultural do Safety Attitudes Questionnaire - Short Form 2006 para o Brasil. Rev Lat Am Enfermagem [Internet]. 2012 [cited 2016 Aug 15];20(3):575-82. Available from: http://www.scielo.br/pdf/rlae/ v20n3/pt_a20v20n3.pdf

11. Terwee CB, Bot SDM, de Boer MR, van der Windt DAWM, Knol DL, Dekker J, et al. Quality criteria were proposed for measurement properties of health status questionnaires. J Clin Epidemiol [Internet]. 2007 [cited 2016 Aug 20];60(1):34-42. Available from: http://www.jclinepi.com/ article/S0895-4356(06)00174-0/pdf

12. Carvalho PA, Göttems LBD, Pires MRGM, Oliveira MLC. Cultura de segurança no centro cirúrgico de um hospital público, na percepção dos profissionais de saúde. Rev Lat Am Enfermagem [Internet]. 2015 [cited 2016 Aug 20];23(6):1041-8. Available from: http://www.scielo.br/pdf/ rlae/v23n6/pt_0104-1169-rlae-23-06-01041.pdf

13. Carvalho REFL, Arruda LP, Nascimento NKP, Sampaio RL, Cavalcante MLSN, Costa ACP. Assessment of the culture of safety in public hospitals in Brazil. Rev Lat Am Enfermagem [Internet]. 2017 [cited 2017 May 20];25:e2849. Available from: https://www.ncbi.nlm.nih.gov/pmc/ articles/PMC5363325/pdf/0104-1169-rlae-25-e2849.pdf

14. Machado MH, Aguiar Filho W, Lacerda WF, Oliveira E, Lemos W, Wermelinger M, et al. Características gerais da enfermagem: o perfil sociodemográfico. Enferm Foco [Internet]. 2016 [cited 2016 Aug 12];7(Spec No):9-14. Available from: http://biblioteca.cofen.gov.br/wpcontent/uploads/2016/07/Caracter\%C3\%ADsticas-gerais-da-enfermagem-o-perfil-s\%C3\%B3cio-demogr\%C3\%A1fico.pdf

15. Vaitsman J. Gerencialismo, cultura e expectativas entre os servidores públicos de saúde. Rev Adm Pública. 2001 [cited 2018 Apr 14];35(1):2948. Available from: http://bibliotecadigital.fgv.br/ojs/index.php/rap/article/view/6360/4945

16. Oliveira RM, Leitão IMTA, Aguiar LL, Oliveira ACS, Gazos DM, Silva LMS, et al. Evaluating the intervening factors in patient safety: focusing on hospital nursing staff. Rev Esc Enferm USP [Internet]. 2015 Feb [cited 2018 Apr 14];49(1):104-13. Available from: http://www.scielo.br/pdf/ reeusp/v49n1/0080-6234-reeusp-49-01-0104.pdf

17. Sexton J, Helmreich R, Neilands T, Rowan K, Vella K, Boyden J, et al. The Safety Attitudes Questionnaire: psychometric properties, benchmarking data, and emerging research. BMC Health Serv Res [Internet]. 2006 [cited 2016 Aug 20];6(44):1-10. Available from: https:// www.ncbi.nlm.nih.gov/pmc/articles/PMC1481614/pdf/1472-6963-6-44.pdf

18. Relihan E, Glynn S, Daly D, Silke B, Ryder S. Measuring and benchmarking safety culture: application of the safety attitudes questionnaire to an acute medical admissions unit. Ir J Med Sci [Internet]. 2009 [cited 2016 Aug 17];178(4):433. Available from: https://doi.org/10.1007/ s11845-009-0352-2

19. Lee WC, Wung HY, Liao HH, Lo CM, Chang FL, Wang PC, et al. Hospital safety culture in Taiwan: a nationwide survey using Chinese version safety attitude questionnaire. BMC Health Serv Res [Internet]. 2010 [cited 2016 Aug 20];10:234. Available from: https://bmchealthservres. biomedcentral.com/articles/10.1186/1472-6963-10-234

20. Rigobello MCG, Carvalho REFL, Cassiani SHB, Galon T, Capucho HC, de Deus NN. Clima de segurança do paciente: percepção dos profissionais de enfermagem. Acta Paul Enferm [Internet]. 2012 [cited 2016 Aug 12];25(5):728-35. Available from: http://www.scielo.br/pdf/ ape/v25n5/13.pdf

21. McGuire MJ, Noronha G, Samal L, Yeh H-C, Crocetti S, Kravet S. Patient safety perceptions of primary care providers after implementation of 
an electronic medical record system. J Gen Intern Med [Internet]. 2013 [cited 2016 Aug 20];28(2):184-92. Available from: https://www.ncbi. nlm.nih.gov/pmc/articles/PMC3614133/pdf/11606_2012_Article_2153.pdf

22. Olsson C, Forsberg A, Bjerså K. Safety climate and readiness for implementation of evidence and person centered practice - a national study of registered nurses in general surgical care at Swedish university hospitals. BMC Nursing [Internet]. 2016 [cited 2017 May 15];15:54. Available from: https://bmcnurs.biomedcentral.com/track/pdf/10.1186/s12912-016-0174-2?site=bmcnurs.biomedcentral.com

23. Ting WH, Peng FS, Lin HH, Hsiao SM. The impact of situation-background-assessment-recommendation (SBAR) on safety attitudes in the obstetrics department. Taiwan J Obstet Gynecol [Internet]. 2017 [cited 2017 May 15];56(2):171-4. Available from: http://www.tjog-online. com/article/S1028-4559(17)30009-8/pdf

24. Speroff T, Nwosu S, Greevy R, Weinger MB, Talbot TR, Wall RJ, et al. Organisational culture: variation across hospitals and connection to patient safety climate. Qual Saf Health Care [Internet]. 2010 [cited 2016 Aug 20];19(6):592-6. Available from: http://dx.doi.org/10.1136/ qshc.2009.039511

25. Magalhães AMM, Dall'Agnol CM, Marck PB. Carga de trabalho da equipe de enfermagem e segurança do paciente: estudo com método misto na abordagem ecológica restaurativa. Rev Lat Am Enfermagem [Internet]. 2013 [cited 2017 May 13];21(Spe No):146-54. Available from: http://www.scielo.br/pdf/rlae/v21nspe/pt_19.pdf

26. de Vries EN, Ramrattan MA, Smorenburg SM, Gouma DJ, Boermeester MA. The incidence and nature of in-hospital adverse events: a systematic review. BMJ Qual Saf [Internet]. 2008 [cited 2018 Feb 02];17(3):216-23. Available from: qualitysafety.bmj.com/content/17/3/216

27. Mendes W, Pavão ALB, Martins M, Travassos C. The application of Iberoamerican study of adverse events (IBEAS) methodology in Brazilian hospitals. Int J Qual Health Care. [Internet]. 2018 Jul [cited 2018 May 9];30(6):480-5. Available from: https://academic.oup.com/intqhc/ article/30/6/480/4958028

28. Agência Nacional de Vigilância Sanitária (BR). Assistência segura: uma reflexão teórica aplicada à prática [Internet]. 2a ed. Brasília: ANVISA; 2017 [cited 2018 May 9]. 170 p. (Série Segurança do paciente e qualidade em serviços de saúde). Available from: http://portal.anvisa.gov.br/ documents/33852/3507912/Caderno+1+-+Assist\%C3\%AAncia+Segura+-+Uma+Reflex\%C3\%A3o+Te\%C3\%B3rica+Aplicada+\%C3\%A0+Pr \%C3\%A1tica/97881798-cea0-4974-9d9b-077528ea1573 